\title{
ANTROPOLOGIA I ETYKA NADZIEI *
}

\author{
UWA.GI WSTEPNE
}

W tradycji filozoficznej i teologicznej próbowano podchodzić do zagadnienia „nadziei” na dwa różne sposoby. W filozofii antycznej nadzieję uważano za pewien rodzaj namiętności (Leidenschaft). Jako przeciwieństwo przyporządkowywano jej bojaźń. Mówiło się też o innych parach namiętności, a mianowicie o radości i smutku oraz o miłości i nienawiści. Inną drogę do tego zagadnienia obrała teologia chrześcijańska. Nadzieja była dla niej, obok wiary i miłości, jedną z ,boskich” cnót.

$\mathrm{Z}$ tych dwóch sposobów potraktowania zagadnienia nadziei wynikała podwójna rola dla jakiejś antropologii oraz podwójne zadanie dla etyki. Jeżeli mianowicie nadzieja jest jakąś namiętnością, to wtedy antropologia nadziei powinna ukazywać, w jaki sposób owa nadzieja - podobnie jak wszystkie inne namiętności - wyplywa z natury człowieka. Zadaniem etyki byłoby natomiast ukazanie drogi do jakiegoś opanowania tej namiętności. Jeśli zaś nadzieja jest pewną cnotą, wówczas etyka powinna człowiekowi pomagać w odnajdywaniu ,złotego środka” pomiędzy dwoma występkami, czyli w tym wypadku pomiędzy zarozumiałością i zwątpieniem. Antropologia natomiast musi pokazywać czy przy pomocy laski Bożej człowiek jest w ogóle zdolny - a jeśli tak, to na jakiej drodze do odnajdywania owego złotego środka. W niniejszych rozważaniach ukażemy specyfikę obu tych ujęć. Przede wszystkim zaś zostanie postawione pytanie, czy i w jaki sposób obydwa te rozumienia nadziei mogą się ze sobą wiązać.

\section{CZESC PIERWSZA: NADZIEJA JAKO NAMIĘTNOSC}

\section{O namiętności w ogólności}

a) Namiętności a natura człowieka - napięcie pomiędzy alctywnościa życiowa a warunkami $\dot{z} y c i o w y m i$

Namiętności wypływają z natury człowieka. Dla objaśnienia tego

* Niniejszy artykuł jest przekładem adczytu, jaki w maju 1984 r. w Papieskiej Akademii Teologicznej $\mathrm{w}$ Krakowie wygłosił R. Schaeffler - profesor Uniwersytetu w Bochum. 
związku konieczne jest przypomnienie niezwykle pomocnej, tradycyjnej definicji pojęcia „natury”. Powiada ona: „Naturą jest istota jakiegoś bytu, o ile stanowi ona zasadę, z której wypływają jego akty". Odnosi się to również do istoty, natury i aktów człowieka. Nasza ludzka ,istota” ujawnia się w tym, że wypływają z niej określone akty, które — właśnie dlatego, iż spełniane są dzięki naszej "naturze" - nie dają się podporządkować naszej woli. Widać to przede wszystkim na fizycznych oznakach naszego życia: nie możemy istnieć bez oddychania, bez przyswajania sobie odpowiednich substancji i sił, które czerpiemy z naszego otoczenia. To samo odnosi się również do funkcjonowania naszego życia duchowego. Jako podmioty nie możemy istnieć naprawdę, jeśli nie spełniamy aktów myślenia i poznawania. Fakt, że musimy oddychać, jeść, a także myśleć i poznawać, jest koniecznością, która wynika z naszej natury.

Jednakże to, że coś musimy, nie świadczy o naszych rzeczywistych możliwościach. Nie jest również pewne, że środowisko naszego fizycznego i psychicznego życia stwarza nam warunki, umożliwiające nam oddychanie, jedzenie czy też poznawanie. Musimy oddychać, odżywiać się, ale nie dysponujemy powietrzem czy pożywieniem wyłącznie dlatego, że ich koniecznie potrzebujemy. Zaś obiektywny świat, który wychodzi nam naprzeciw, może być aż tak bezładny, pogrążony w sprzecznościach, i aż tak „zwariowany”, że w zetknięciu z nim zatracamy zdolność myślenia i poznawania. W języku potocznym mówimy wtedy bardzo trafnie, że „można zwariować”.

M u s imy więc w jakiś określony sposób być aktywni. Nie jest jednak pewne, czy znajdujemy warunki, dzięki którym mo że my być aktywni w ten właśnie sposób. Nasze namiętności powstają w wyniku doświadczenia możliwości konfliktu pomiędzy koniecznością naszej natury a uwarunkowaniami naszego otoczenia. Ilekroć bowiem znajdujemy się w sytuacjach, w których nie jest możliwe spełnianie aktów właściwych naszej naturze, odczuwamy je jako ,sprzeczne z naturą". Namiętnie dążymy do zdobycia tego, dzięki czemu możemy oddychać i myśleć; dzięki czemu możemy żyć zarówno cieleśnie jak i duchowo. Stąd mamy możliwość - w pewnych granicach - kierowania konkretnym aktem namiętności, a nawet stłumienia go. W samym swym źródle namiętności nie są jednak zależne od naszego upodobania w takim samym stopniu, w jakim od tego upodobania jest niezależna nasza natura. O tyle też walka z namiętnościami wydaje się być tak samo daremna, jak walka z naszą własną, ludzką naturą. Dlatego też namiętności możemy doświadczać jako obcych sil, które są potężniejsze niż nasza wola. Odnosi się to również — jak się okaże - do namiętności, jaką jest nadzieja. 
b) Namiętności jako niebezpieczeństwo

Namiętności, jak to zostało powiedziane, pochodzą z naszej natury, tzn. z naszej ludzkiej istoty, o ile istota ta jest źródłem określonych aktów. Dlatego właśnie z namiętnościami może się wiązać potrójne niebezpieczeństwo dotyczące: naszego poznania, naszej praktyki, a przede wszystkim naszej wolności. Namiętności mogą sprawić, że nasze p o z n an i e zamieni się w sposób niezauważalny w jakieś ,marzycielstwo" (Wunschdenken), którym chcielibyśmy potem usprawiedliwiać to, do czego już przez cały czas nieuchronnie dążyliśmy. Jeśli temu niebezpieczeństwu ulegniemy, wtedy nasza praxis zostanie pozbawiona kierownictwa ze strony bezstronnego rozumu; nie będziemy wtedy zdolni do krytycznej refleksji nad celami, które sobie wyznaczyliśmy oraz nad wyborem naszych dróg. Jednak w sposób szczególny namiętności zagrażają naszej wolności. Ze względu na ich zakorzenienie $w$ naszej naturze, namiętności zdają się nie pozwalać na żaden wybór, zniewalają nas ,od wewnątrz", a to wewnętrzne zniewolenie równocześnie powoduje, że poddajemy się zewnętrznym zależnościom. Rzeczy bowiem, ludzie lub stosunki, umożliwiające osiąganie celu naszych namiętnych pragnień, zmuszają nas do uległości. Już teraz można wskazać na to, że właśnie namiętność nadziei może — w sposób szczególnie wyraźny — stać się źródłem takiej niewoli. To właśnie nasze nadzieje (i odpowiadające im lęki) skłaniają nas do podporządkowywania się najrozmaitszym zarządzeniom innych.

c) Namiętności jako szansa

Ludzkie namiętności są nie tylko niebezpieczeństwami. Stanowią one także pewną specyficzną — i tym razem również potrójną — szansę: dla naszej teorii, dla naszej praktyki oraz dla spełnienia się naszej ludzkiej wolności. Dążenie bowiem do poznania bez namiętności stałoby się zwykłą ciekawością; wszelkie działanie pozbawione namiętności zamienia się w samą tylko funkcję, która pozostaje w stosunku do nas czymś zewnętrznym i zagraża naszej tożsamości. Zaś wolność bez namiętności nie byłaby już zakorzeniona w naszej naturze i, jako taka, byłaby czymś dowolnym, pozbawionym orientacji i kierunku. Dzięki naszym namiętnościom, o ile wypływają one z naszej natury, wiemy, co naprawdę wchodzi w grę przy decyzjach naszej woli i jak dalece konieczne jest, żeby w każdy z naszych wolnych czynów angażować całą naszą egzystencję. 


\section{Namiętność nadziei}

a) Nadzieja i natura człowieka - antycypacja spotkań, które umożliwiaja $\dot{z} y c i e$

Również i nadzieja należy do owych aktów, które swoją zasadę wywodzą z naszej ludzkiej istoty. Podobnie jak inne namiętności, wypływa ona z ludzkiej natury. Nadzieja wypływa jednak z tej natury w sposób specyficzny: jako antycypacja spotkań, dzięki którym możliwą staje się ludzka praktyka, i to nie jakaś praktyka dowolna, lecz taka, która warunkuje nasze życie. Z zasobów stanowiących nasz rzeczywisty świat i nasze środowisko, musimy być wciąż na nowo obdarowywani możliwościami, których potrzebujemy do życia po ludzku. Ten, kto jest głodny i spodziewa się pokarmu; kto stawia pytania i poszukuje właściwych odpowiedzi; kto jest samotny i tęskni za ludzkim spotkaniem, ten wie (nawet jeśli sobie tego wyraźnie nie uświadamia), iż wszystkie te akty, które człowiek musi spełniać, aby żyć po ludzku, stają się możliwe tylko w spotkaniu z rzeczywistością przyrody (Umwelt) oraz w spotkaniu z ludźmi ze swojego otoczenia (Mitwelt). Równocześnie zdaje on sobie sprawę z tego, że spotkań takich nie można wymusić. Nadzieja jest antycypacją takich spotkań z ludźmi i rzeczami, które to spotkania dopiero nas uzdalniają do tego, żeby żyć, działać, myśleć i kochać. Antycypacja spotkania - jako taka - stanowi jakąś namiętność, która z wewnętrzną koniecznością określa zarówno naszą teorię, jak i praktykę. Dlatego do nadziei odnosi się również wszystko, co można powiedzieć o każdej namiętności: jest ona niebezpieczeństwem i szansą równocześnie.

b) Niebezpieczeństwa zwiazane $z$ nadzieja: teoretyczne $i$ praktyczne dualizmy

Miłość, nienawiść, radość, smutek i gniew odnoszą się zasadniczo do tego, co teraźniejsze. Natomiast nadzieja jako namiętność odnosi się do spotkania, które ma nastąpić w przyszłości, otwierając przed tym, kto żywi nadzieję, możliwości dla jego własnego życia. Ponieważ nadzieja odnosi się całkowicie do przyszłości, dlatego łatwo zdarza się, że tę rzeczywistość, której aktualnie doświadczamy, przeciwstawiamy nagle temu, co możliwe i do czego dopiero namiętnie dążymy, czego oczekujemy od przyszłości. W ten sposób nadzieja staje się źródłem jakiegoś ,dualizmu”, jakiegoś nieoczekiwanego przeciwstawienia. Teraźniejszości, której doświadczamy jako niewystarczającej, jako domagającej się przezwyciężenia, a nawet jako czegoś złego; potęgom przeszłości, poprzez którą te- 
raźniejszość ta jest określana, przeciwstawiamy w konsekwencji oczekiwaną i dobrą przyszłość, jako niespodziewane przeciwieństwo. Jednakże wszędzie tam, gdzie ,dobra przyszłość” jest niespodziewanie przeciwstawiana „złej przeszłości i teraźniejszości”, nie da się na dalszą metę uniknąc teologicznego i antropologicznego dualizmu. W sensie teologicznym będziemy mianowicie mieli do czynienia $\mathrm{z}$ rozdarciem pomiędzy stworzeniem ,,na początku” i zbawieniem „,w dniu ostatecznym”, zaś w sensie antropologicznym ciało, które jest ukształtowane na drodze dziedziczenia, będzie przeciwstawiane duszy, która dzięki swoim wolnym czynom ma zdobyć uczestnictwo w przyszłym świecie. Przyczyną, która wywołuje te dualizmy jest zawsze namiętność nadziei. A oto, w jaki sposób ów dualizm wpływa na naszą praktykę: marzenie o jakimś radykalnie przyszłym dobru, o jakiejś radykalnie dobrej przyszłości z jednej strony wyzwala potężne siły, potrzebne do przekształcania przyrody i społeczeństwa; z drugiej zaś zupełnie nie uwzględnia tego, co jest faktycznie możliwe w warunkach konkretnej sytuacji świata. Zabsolutyzowana nadzieja przemienia się zwykle w gniew w stosunku do rzeczywistości; owszem, przemienia się nawet w namiętność, która usiłuje zniszczyć i oddalić ,złą rzeczywistość”, robiąc miejsce „dobrej przyszłości”.

Wymienione dualizmy, które odnoszą się do naszej teorii i praktyki, stanowią równocześnie zagrożenie dla naszej wolności. Człowiek, który w sposób namiętny żywi nadzieję, nie może już krytycznie rozważać stawianych sobie celów i wybranych przez siebie dróg, ponieważ wydaje mu się, że od treści jego oczekiwań zależy w ogóle możliwość jego ludzkiego bytowania. Nie ma on żadnego dystansu w stosunku do swojej nadziei, lecz jest w niej całkowicie pogrążony. Nie jest on ani zdolny ani gotowy do tego, by krytykować i korygować swoje wyobrażenia na temat wyczekiwanej przyszłości. Stąd, w ocenie ludzi sobie współczesnych, uchodzi za osobę niewolniczo przytwierdzoną do swoich niezmiennych, wymarzonych obrazów. Woli on raczej podjąć walkę na śmierć i życie z istniejącą rzeczywistością, niż postawić sobie pytanie, czy przypadkiem nie stworzył sobie fałszywego obrazu przyszłości, której się spodziewa.

\section{c) Szanse ze strony namiętnej nadziei}

Podobnie jak wszystkie namiętności, tak i namiętność nadziei kryje w sobie nie tylko niebezpieczeństwa, ale również pewne szanse dla naszego poznania, dla naszej praktycznej działalności oraz dla korzystania $\mathrm{z}$ naszej wolności. $\mathrm{Z}$ teoretycznego punktu widzenia namiętność nadziei przypomina nam o tym, że wszelkie poznanie ma charakter uprzedzający, że „wmyśla się” (gr. ennoei) ono niejako w istotę 
rzeczy, aby zrozumieć, jakie jest ich wewnętrzne ukierunkowanie (,czym zdają się być" - jak mówił Platon). Z praktycznego punktu widzenia namiętność nadziei chroni nas przed niebezpieczeństwem popadnięcia w dwojaką rezygnację: $1^{\circ}$ - ucieczkę $w$ marzenia o jakimś lepszym świecie, pojawiające się wówczas, gdy nie wierzymy już, że w istniejącym świecie jest jeszcze coś do zrobienia; $2^{\circ}$ - poddanie się istniejącemu światu, któremu zwykle już się nie przeciwstawiamy od chwili utraty wiary, że nasz opór może jeszcze coś zmienić.

Namiętność nadziei jest wreszcie cenną szansą właściwego rozumienia i skutecznego realizowania naszej ludzkiej wolności. Jedynie Bóg bowiem nie musi żywić namiętnej nadziei. Może On, jeśli tylko zechce, nadawać światu nowe kształty, rozpoczynając całkowicie od zera. Może On również, jeśli tylko zechce, skończyć z jakimś światem, który uzna za zły. Natomiast ludzka wolność nigdy nie jest w stanie spowodować absolutnego początku lub absolutnego końca. Zamiast tego, posiada ona zdolność do takiego wybierania konkretnych, doczesnych - dlatego zawsze tymczasowych i względnych - możliwości działania, żeby byly one przejrzyste, tzn. by, mimo swojej relatywności, umożliwiały nam patrzenie w kierunku absolutnych celów naszej nadziei. Nadzieja uczy nas, żebyśmy nasze życie, mające zawsze wyłącznie względną wartość, uważali za przejrzyste światło, które pozwala nam dostrzegać pewien dar bezwarunkowy dar miłości ze strony Stwórcy. Dzięki nadziei możemy pozwolić na odrywanie się od nas naszym dziełom, które posiadają zawsze jedynie relatywną wartość, i które przez to mogą uzyskiwać względem nas swoją autonomię; możemy wypuszczać z rąk nasze dzieło w nadziei, że zostaniemy obdarowani nadwyżką dzieła w stosunku do naszego działania. Sprawę, o której mówimy, można zilustrować dwoma przykładami. Pierwszy przykład to dzieło sztuki. Artyście, który je wypuścił z rąk objawia się ono jako pewien dar, który jest czymś większym niż wszystko to, czego on sam „dokonał”. Drugim przykładem jest sakrament, w którym to, co zostało rzeczywiście zdziałane (opus operatum), zawsze nieskończenie przerasta osobisty wkład szafarza tegoż sakramentu (opus operantium). Nadzieja jako namiętność skierowuje się $\mathrm{w}$ trakcie działania na takie dzieło, które przewyższa wszystko to, co my jesteśmy w stanie uczynić. Dlatego, z jednej strony, uwalnia nas od konieczności i chęci „wytwarzania” tego, co stanowi przedmiot nadziei. Z drugiej strony, uwalnia nas ona od rezygnacji, która z góry zakłada, że nie jesteśmy już w stanie niczego dokonać. Namiętność nadziei obdarowuje nas wolnością bez iluzji. 
3. Zarys antropologii nadziei jako namiętności

Ludzkie namiętności, a wśród nich nadzieja, stanowią sposoby, przy pomocy których nasza ludzka istota ukazuje się jako „natura”, tzn. jako „zasada naszych aktów”. Widocznie człowiek jest taką istotą, która przez swoją naturę czuje się zmuszona, by w stosunku do wszelkich ,,nagich faktów" zajmować postawę krytyczną, zarówno pod względem teoretycznym jak i praktycznym. Pod względem teoretycznym namiętność nadziei skłania nas, byśmy za pośrednictwem myślenia ujmowali ów ruch, dzięki któremu sama rzeczywistość wychodzi poza swój aktualny stan, kierując się ku przyszłym możliwościom. Pod względem praktycznym namiętność ta uzdalnia nas do tego, żebyśmy w świecie samych faktów mogli uchwytywać zobowiązującą moc tego, co możliwe. Człowiek, w którego naturze leży namiętność nadziei, jest istotą zdolną do przemieniania każdej danej mu sytuacji w jakieś zadanie. Ponieważ jednak nadzieja — jak się okazało - jest czymś innym aniżeli duma z własnych dokonań, dlatego namiętność nadziei uzdalnia człowieka również do tego, by każdy jego czyn, każde spełnione przez niego zadanie było otwarte (transparent) na dar, który może otrzymać, dar wykraczający poza wszelką własną działalność. Antropologia namiętnej nadziei wykazuje, że człowiek jest istotą, dla której każdy dar może się stać zadaniem, zaś każde działanie może być darem.

4. Wstęp do etyki nadziei jakonamiętności (uwaga dotycząca pozytywnego doświadczenia ludzkiej przygodności)

Zadanie etyki $\mathrm{w}$ odniesieniu do namiętności, a więc i namiętności nadziei, nie polega na tym, by nasze namiętności tłumić, nie polega ono również na tym, by $\mathrm{z}$ namiętności uczynić najwyższą instancję, której rola polegałaby na osądzaniu naszego poznania i postępowania. Zadanie etyki polega raczej na wykorzystywaniu bodźców, mających swe źródło w namiętności, w celu uczłowieczania naszej teorii i naszej praktycznej aktywności. Takiemu uczłowieczaniu naszej teorii i naszego życia namiętność nadziei może być pomocna głównie na dwa sposoby. Po pierwsze, przeciwstawia się ona wszelkiej pokusie rezygnacji i nie dopuszcza do tego, żebyśmy się zadowalali istniejącym światem. Z drugiej strony namiętność nadziei demaskuje stoicki ideał niewzruszalności (ataraksja) jako pewną fikcję. Ktoś, kto w namiętny sposób żywi nadzieję, wie, że istnieją sprawy, o które musimy się troszczyć i niepokoić. Można powiedzieć, że namiętność nadziei, już niejako sama przez się, przeciwstawia się niesłusznej rezygnacji oraz błędnie wytyczonemu celowi stoickiej nie- 
wzruszoności. Jednak konieczna jest jakaś uświadomiona kultura nadziei, żeby można ją było w ogóle odróżnić od nierealnych marzeń. Tylko ten, kto uczy się takiego odróżniania, będzie zdolny do odnajdywania w aktualnie napotykanej rzeczywistości swego życia owej zobowiązującej możliwości, w którą się angażuje, aby określić zadanie, jakiemu może się oddać, urzeczywistniając w ten sposób siebie samego. Jedynie „wykształcona nadzieja”, „docta spes”, uzdalnia nas do doświadczenia, w którym wszystko, co się nam „przytrafia” (contingit) z zewnątrz, otwiera nam drogę do samych siebie, do urzeczywistnienia własnej istoty. Przed etyka nadziei staje więc zadanie ukazywania przygodności jako szansy dla odnajdywania samego siebie. Odpowiedzialna etycznie namiętność nadziei, która uwrażliwia nas na tego typu rodzaju doświadczenia, uzdalnia nas równocześnie do przeżywania takiego szczęścia, które dostępne jest jedynie człowiekowi. Znaczy to, że nie powinniśmy szukać szczęścia, właściwego Bogu, który sam sobie wystarcza, ale szczęścia na miarę skończonego człowieka, który pośród tymczasowości swojego życia antycypuje jakąś absolutną przyszłość.

\section{CZESSC DRUGA: NADZIEJA JAKO „CNOTA BOSKA"}

1. Pojęcie, ,c nót boskich" w ogólności (relacja wolności do wolności jako ich źródło)

Przez „cnotę” w sensie moralnym rozumiemy pewną trwałą dyspozycję (habitus), którą nabyliśmy poprzez szereg wolnych decyzji i która raz nabyta - uzdalnia nas do wybierania tego, co słuszne w konkretnej sytuacji, wymagającej często szybkiego rozstrzygania. Aczkolwiek ta nabyta, trwała postawa (habitus acquisitus) stanowi wynik wielokrotnych aktów wolności, to jednak - $\mathrm{z}$ chwilą, kiedy już raz ją nabyliśmy nadaje ona przyszłym aktom tej wolności ową „lekkość”, dzięzi której cnota ukazuje się nam, jak mawiał Fryderyk Schiller, równocześnie jako wdzięk i moralne piękno, albo też — posługując się słowami Kanta obdarowuje człowieka „radosnym sercem przy wypełnianiu danego obowiązku". Inaczej jest w przypadku, gdy ktoś nie nabył jeszcze trwałej postawy cnoty. Każdą słuszną decyzję musi on sobie każdorazowo wywalczyć w ascetycznym trudzie podejmowania wartościowych etycznie działań.

„Boską" nazywamy jakąś cnotę dla pokreślenia, że wolność, z której ona wypływa oraz lekkość, którą nadaje słusznie podjętym decyzjom, wynikają z łaskawej dobroci Boga. Cnoty takie są „umiejscawiane” w pewnym procesie, który teologia nazywa „uświęcaniem człowieka”, a zatem 
w ,kontekście soteriologicznym", albowiem w sensie ściśle teologicznym pojęcie „łaski” musi być zawsze rozumiane przede wszystkim soteriologicznie, tzn. jako łaska zbawienia i przebaczenia. Cnoty boskie, pochodzące od darmowej, ale skutecznej łaski Bożej są mocami, czerpanymi z radości, jaką sprawia nam otrzymane przebaczenie. Greckie słowo charis i łacińskie słowo gratia oznaczają ,łaskawość” ale i „wdzięcznośc”, a zatem z jednej strony dar wolnej woli, z drugiej zaś radosną odpowiedź. Ponadto $\mathrm{w}$ pojęciach tych dochodzi do głosu jeszcze inny moment. Otóż greckie „Charyty” i łacińskie „Gracje” uchodziły w języku pogańskim za boginie pełnego swobody tańca. Łaskawość i wdzięczność, dar i radosna odpowiedź powodują pewną swobodę, która z naturalną pewnością kieruje naszymi krokami w taki sposób, że dobro jest doświadczane równocześnie jako piękno.

Radość z doznanego pojednania i naturalna pewność, z jaką owa radość kieruje naszymi krokami wywołują potrójny skutek: 1) w chwilach pokusy uzyskujemy miejsce na twardym gruncie, 2) w doświadczeniach niemocy znajdujemy jakieś wyjście, 3) możemy odzyskiwać samych siebie właśnie tam, gdzie siebie bezinteresownie oddajemy. Nietrudno dostrzec, że te trzy skutki owej radości, która wynika z otrzymanego przebaczenia, zbiegają się z trzema ,cnotami boskimi”: z wiarą, która obdarza nas twardym gruntem pod nogami (hypostasis, emunah); z nadzieją, która upewnia nas co do drogi i z miłością, która uzdalnia nas do odnajdywania siebie wszędzie tam, gdzie siebie oddajemy.

\section{O cnocie nadziei}

a) Nadzieja a ,dialektyka praktycznego rozumu”

Nadzieja to doskonały wzór, na podstawie którego możemy dobrze odczytywać różnicę, jaka zachodzi pomiędzy cnotami naturalnymi a cnotami boskimi. Nadzieja bowiem - w przeciwieństwie do wielu innych, trwałych dyspozycji, mających wartość moralną - nie jest skutkiem rozumowego kształtowania naturalnych motywów naszego postępowania. Swoją trwałość i zdecydowaną orientację zawdzięcza ona Bogu i Jego wierności; tej wierności, która otwiera przed człowiekiem nowe drogi właśnie tam, gdzie wszelkie ludzkie możliwości osiągnęły już ostateczną granicę. Przy czym, nie chodzi tu o zewnętrzną granicę, której doświadczamy w chwili, gdy nasza moc zaczyna współzawodniczyć z jakimiś obcymi siłami. Chodzi tutaj o rodzaj wewnętrznego zagrożenia, które za Kantem - nie przyjmując w szczegółach całej jego argumentacji - można nazwać „dialektyką rozumu praktycznego". 
Nadzieja jako namiętność jest pewna swojej słuszności. Człowiek, który żywi nadzieję, a w istniejących warunkach nie osiąga tego, do czego tęskni, ma poczucie słuszności w stosunku do „złego świata”, który odmawia mu tego, co mu się należy. Zaś nadzieja jako cnota boska - o czym tutaj mówimy - jest w pełni świadoma, że nie może sobie rościć żadnego prawa do spełnienia swej tęsknoty. Właśnie ta samokrytyczna świadomość jest przede wszystkim ugruntowana w naszej moralnej samoocenie. Prawo moralne jest dla nas zawsze jakimś imperatywem, czyli jakimś nakazem, któremu „stary człowiek” w nas musi być podporządkowany, w ponawianym wciąż trudzie. Dzięki temu dostrzegamy, że jeszcze nie jesteśmy takimi, jakimi powinniśmy być, a więc musimy się stawać lepszymi ludźmi, co dowodzi, że jeszcze nimi nie jesteśmy. W jaki jednak sposób możemy być zdolni do czynienia dobra, skoro nie jesteśmy dobrymi ludźmi? Czy nie zachodzi tu jakaś sprzeczność, która polega na spodziewaniu się dobrych owoców ze złego drzewa?

Zdaniem Kanta, nie można w rzeczywistości uniknąć tej sprzeczności, w którą popada praktyczno-moralny rozum. W przekonaniu Kanta nie można jej też rozwiązać inaczej, jak tylko poprzez nadzieję na jakieś efektywne przebaczenie. W ten sposób usprawiedliwienie grzesznika (iustificatio impii), dokonane przez Boga, staje się jedynym możliwym i koniecznym warunkiem tego, by rozum moralny doszedł do pojednania z samym sobą. Dopiero nadzieja na takie darmowe usprawiedliwienie przez łaskę Bożą chroni nas przed niebezpieczeństwami popadnięcia $\mathrm{z}$ powodu wyrugowania win - w zarozumiałą bezkrytyczność w stosunku do siebie, czy też uwikłania się - za przyczyną świadomości winy w moralne zwątpienie.

b) Potrójna szansa nadziei jako „cnoty boskiej”

Nadzieja jako cnota boska jest - jak to zostało wyżej powiedziane ową siłą, która ma swe źródło w radości spowodowanej faktem, że Bóg w swojej łaskawości przebacza nam grzechy. Siła ta wyposaża człowieka w nieomylną orientację i lekkość, a także dodaje wdzięku (charis) jego poszczególnym czynom. Dlatego ta specyficznie chrześcijańska cnota roztacza przed człowiekiem szczególne możliwości w dziedzinie życia praktycznego i teoretycznego oraz w dziedzinie rozumienia własnej wolności. O doniosłości tych szans przekonujemy się wówczas, gdy uświadomimy sobie różne braki, na które właśnie dzisiaj cierpi ludzka teoria i praktyka.

W dziedzinie praktyki boska cnota nadziei otwiera przed człowiekiem szansę uwolnienia się od konieczności samopotwierdzania siebie (Selbstbestätigung) oraz od konkurującej $\mathrm{z}$ nią konieczności samousprawiedliwiania siebie (Selbstgerechtigkeit). Pojęcie ,samousprawiedliwienia”, w 
rozumieniu św. Pawła, oznacza pewien przymus, któremu podlega człowiek, zmuszający go, by - odgradzając się od innych ludzi - wobec samego siebie i wobec Boga dokonywał oceny własnej wartości. Przymus ten natomiast powoduje, że człowiek nie przyjmuje łaski Bożej, przez co właśnie oddaje siebie pod „panowanie grzechu”. Zatem to, co św. Paweł opisuje przy pomocy pojęć teologicznych, ukazuje się nam dzisiaj - pozornie bez związku z teologią grzechu i zbawienia - jako przyczyna głębokiego kryzysu społecznego. W naszym bowiem społeczeństwie może skutecznie działać tylko ten, kto znajduje aprobatę dla swoich wyobrażeń o celach i normach spolecznego działania. Walka o społeczne wpływy polega głównie na ubieganiu się o taką właśnie aprobatę. Zaś taką walkę o społeczne uznanie może na dalszą metę skutecznie prowadzić tylko ten, kto siebie przedstawia jako reprezentanta „słusznej sprawy”, a swoich konkurentów uważa za reprezentujących „,partykularne interesy jakiejś grupy”. Współzawodnictwo w samousprawiedliwianiu siebie (umiejętność, polegająca na ukazywaniu siebie jako sprawiedliwego, a opozycjonistów jako niesprawiedliwych) staje się w naszym społeczeństwie warunkiem skutecznego działania. Każde oficjalne mówienie o prawie i sprawiedliwości staje się dzisiaj podejrzane właśnie dlatego, że jest jedynie środkiem w walce o społeczne wplywy. Krótko mówiąc, konieczność, która każdego zabiegającego o publiczne uznanie, zmusza do współzawodnictwa w samousprawiedliwianiu, wytwarza w społeczeństwie narastającą wciąż podejrzliwość ideologiczną.

Wobec podwójnego niebezpieczeństwa, że wszelka moralna argumentacja przerodzi się w ideologię, oraz że jakaś rozpowszechniająca się podejrzliwość ideologiczna uniemożliwi każdą moralną argumentację, zagraża nam dzisiaj - w stopniu o wiele większym niż to dostrzegał Kant - samozniszczenie rozumu praktycznego. W takiej sytuacji boska cnota nadziei niespodziewanie uzyskuje całkiem nową aktualność, bowiem dobra nowina o łasce Boga, który usprawiedliwia grzesznika, zawiera w sobie propozycję uwolnienia się spod przymusu samousprawiedliwiania, a tym samym również uwolnienia się spod jarzma ideologii. Człowiek zostaje obdarowany cnotą nadziei wtedy, gdy przebaczenie ze strony Boga wyprowadza go poza alternatywę zarozumiałości i zwątpienia, a mówiąc konkretniej, poza rzekome samousprawiedliwienie i podejrzliwość ideologiczną. Kiedy więc uświadamiamy sobie, że cnoty nadziei nie możemy sobie zapewnić własnym wysiłkiem, lecz musimy pozwolić się nią obdarować przez łaskę Bożą, wtedy równocześnie otwierają się i przed nami nowe drogi w zakresie teologicznej teorii. Doświadczenie to bowiem, związane $\mathrm{z}$ podarowaną nam mocą i radością nadziei, stanowi jakby hermeneutyczny klucz do najważniejszych zagadnień, o których można rozprawiać z teologicznego punktu widzenia. 
Teologicznie mówić o Bogu znaczy tyle, co mówić o Tym, który poprzez swoją wierność (również w stosunku do niewiernego i grzesznego człowieka) zawsze umożliwia nadzieję. Mówić zaś teologicznie o świecie, znaczy równocześnie tyle, co pojmować całą rzeczywistość jako pewien układ znaków, które otwierają przed nami drogi nadziei. I mówić teologicznie o człowieku znaczy tyle, co opisywać go jako istotę, która jest powołana do nadziei i która jedynie dzięki nadziei może żyć.

Tym samym więc stało się jasne, że boska cnota nadziei otwiera nowe możliwości właści i e go uży tkowania i właściwego rozumienia $1 \mathrm{udzkiej}$ wolności. Wszędzie tam, gdzie człowiek spodziewa się sprawiedliwości jako rezultatu własnego działania, popada w błąd zarozumiałości (samousprawiedliwiania), a następnie pogrąża się w zwątpieniu (ponieważ podejrzliwość ideologiczną musi skierować przeciwko sobie samemu). W ten sposób traci on jednak zdolność do moralnego samookreślania, czyli po prostu gubi swoją wolność. A zatem, cnota nadziei, która - jako jedyna - jest w stanie rozwiązać problem dialektyki praktycznego używania rozumu, przywraca człowiekowi na nowo jego moralną wolność.

c) Trojakie zagrożenie cnoty nadziei

Cnotę nadziei należy określać nie tylko ,z zewnątrz”, w stosunku do takich występków jak zarozumiałość czy zwątpienie. Istnieją również niebezpieczeństwa, które wypływają ze samej nadziei i zagrażają jej „od wewnątrz. Niebezpieczeństwa te odnoszą się przede wszystkim do naszej praktyki. Pewność, że - jak powiada św. Paweł — „nic nie może nas odłączyć od miłości Boga" (Rz 8, 39), może nas łatwo skłonić do mniemania, iż w owej alternatywie, przed którą zostajemy postawieni w trakcie naszego działania, niczego się już nie ryzykuje. Człowiek, który żywi nadzieję już niejako z góry zdaje się wiedzieć, że świat nie będzie mu przynosił niczego innego, jak tylko same udręki. W gruncie rzeczy nie chodzi mu też o nic innego jak tylko o to, żeby nie utracić „,chwały człowieka umęczonego" (Ruhm der Bedrängnis). Jednak na skutek tego nie odkrywa on już w swoim otoczeniu życiowym żadnych nowych możliwości, które mogłyby go sprowokować do podjęcia decyzji. Nadzieja, ta wybitnie praktyczna cnota, doprowadza w końcu do całkowitej utraty praktycznych umiejętności.

Z utratą wymienionych umiejętności łączą się niebezpieczeństwa co do rozumienia i realizowania wolności. Radość, która płynie z przebaczenia grzechów, doprowadza niektórych chrześcijan do jakiejś osobliwej euforii, która czuje się zwolniona od wszelkiej walki z własną słabością i od powiązań z maszynerią tego świata. Często łączy się z tym pewna 
specyficzna fascynacja, która nie odrywa się od widoku przepaści i ciemności. Nadzieja usiłuje wzmocnić swoją pewność przez to, że - ilekroć rozpatrujemy ją poza dobrą nowiną o Bożej łasce - zachwyca się, a nawet upaja beznadziejnością świata i naszego własnego życia. Wolność polega wtedy przeważnie na tym, żeby - przyglądając się beznadziejności niewybawionego świata — zachować odpowiednio przenikliwe spojrzenie.

Takie błędne rozumienie ludzkiej wolności paraliżuje nie tylko naszą praktykę, ale równocześnie wpływa na teoretyczny stosunek człowieka do świata i do siebie samego. Swiat w swojej realności zostaje mianowicie uznany za radykalnie zepsuty i godny potępienia. Istniejący świat zasługuje na uwage, jedynie wtedy, gdy w swojej jakości jest traktowany jako znak, wskazujący na jakiś przyszły, całkowicie inaczej urządzony świat. Tego rodzaju rozróżnienie pomiędzy światem realnym a światem rozumianym jako znak, zmienia zarazem koncepcję człowieka. Także i on uchodzi w swojej realności za jakąś cząstkę świata, dla której nie istnieje żadna inna przyszłość oprócz śmierci. Zaś jego godność dostrzega się jedynie $\mathrm{w}$ tym, że jest on pewnym znakiem, który wskazuje na rzeczywistość poza tym światem. O prawdziwej istocie człowieka i o źródle jego ludzkiej godności decyduje nie to, czym jest on w rzeczywistości, lecz jedynie to, ile on znaczy jako znak świata, który ma dopiero nadejść.

3. Elementy etyki nadziei jako cnoty boskiej (uwagi o sposobach dostrzegania aktualnych znaków nadziei i ustanawiania nowych jej znaków)

Przed chwilą była mowa o niebezpieczeństwie, polegającym na tym, że cnota nadziei mogłaby nas pozbawić umiejętności praktycznych, ponieważ nadzieja ta — jeśli tak można powiedzieć - przeskakuje w swojej absolutności nasz tymczasowy świat; ponieważ ten świat - jako nieprzerwane koło utrapień - pozostawia ona poza sobą nie odkrywając już z tego powodu żadnych możliwości, które mogłyby nas zachęcić do działania. Temu niebezpieczeństwu miałaby zapobiegać jakaś etyka nadziei, która naprowadza nas na dostrzeganie ,inkarnacyjnego momentu" obietnicy. Od chwili bowiem Wcielenia owa absolutna przyszłość, której się spodziewamy, stała się już konkretną teraźniejszością. W miejsce wspomnianej fałszywej euforii, która zbyt szybko uważa się za uwolnioną od doświadczenia własnej winy i do zewnętrznych powiązań, oraz w miejsce fascynacji, która ustawicznie spogląda na ciemności i przepaści, jako że światło nadziei ukazuje się nam tylko pośrednio, w postaci cienia, który rzuca świat nieszczęścia i zła - pojawia się jakaś etyka na- 
dziei. Ta etyka nadziei budzi w nas odwagę, byśmy we własnym życiu i działaniu pozwalali się obdarowywać przez zawsze potężniejsze, odnawiające działanie Boga. Dzięki temu możliwą staje się taka praktyka, która w służbie dobra nie zaniedbuje żadnego trudu, a mimo to każdego prawdziwego dobra wyczekuje wyłącznie ze strony przychylnej łaskawości Boga. Dzięki temu jest też możliwe jakieś ustalanie znaków nadziei. Oznacza to, że jesteśmy dalecy od tego, aby naszym bliźnim obiecywać „niebo na ziemi”, ale równocześnie poprzez nasze czyny świadczymy skutecznie o tym, że ta ziemia nie jest wszystkim oraz że nowe niebo i nowa ziemia - dzięki łaskawemu działaniu Boga - już stały się aktualną rzeczywistością. „Głodnych nakarmić, spragnionych napoić, nagich przyodziać..." - tych "siedem uczynków miłosiernych co do ciała" nie rozstrzygnie kwestii głodu, pragnienia czy nagości człowieka w tym świecie. Ten, kto takie zwycięstwo obiecuje, może wywoływać jedynie wciąż nowe rozczarowanie. Ale tam, gdzie te uczynki są spełniane, ludzie mogą doświadczać, że zbawienie, które Bóg obiecał w swojej łaskawości, również dzisiaj "staje się widoczne i skuteczne” (Gaudium et spes, 45). Praktyka, która wypływa z takiej nadziei i która taką nadzieję budzi, ustanawia skuteczne znaki w samym środku doświadczanej rzeczywistości naszego życia. Dlatego dzięki takiej praktyce nadziei, także sakramentalne działanie swój właściwy kontekst uzyskuje dopiero w doświadczanej przez nas rzeczywistości życiowej.

4. Zarys teologicznej antropologii nadziei (,antropologiczna hermeneutyka” bez „,antropologicznej redukcji”)

Poprzednio była mowa o dialektyce praktycznego rozumu. To właśnie tam, gdzie rozum słucha prawa moralnego jako imperatywu i próbuje go przestrzegać, grozi mu niebezpieczeństwo popadania w sprzeczność z samym sobą oraz niebezpieczeństwo unicestwiania samego siebie. Wobec takiego doświadczenia należy uznać, że chcąc mówić o człowieku, należy mówić o takiej istocie, której naturze grozi niebezpieczeństwo unicestwienia samej siebie. Istnieją takie winy i grzechy, które człowieka odczłowieczają, które deprawują jego rozum i które w końcu go wynaturzają, ponieważ „zasada jego aktów” stanowi właśnie fundament pewnej specyficznej umiejętności działania. Dlatego ten, kto chce mówić o człowieku, musi równocześnie mówić o odnowie naszego człowieczeństwa, naszej rozumności, umiejętności działania i naturalności, dla której zawsze potrzeba czegoś więcej niż tylko jakiegoś „naturalnego” wydarzenia. Nasza ludzka natura, której zagraża niebezpieczeństwo znoszenia samej siebie, może się na nowo odradzać tylko dzięki darowi przebaczenia. An- 
tropologia - jako nauka o człowieku, który siebie samego uczynił nieludzkim, stając się przez to zdolnym do człowieczeństwa, tzn. do aktywności właściwej człowiekowi, wyłącznie dzięki darowi przebaczenia ze względu na takie doświadczenia pozostanie już na zawsze nauką o zbawieniu, czyli soteriologią. Teologia nadziei jest w stanie rozwijać te badania w taki sposób, by powstawała $\mathrm{z}$ tego jakaś całościowa antropologia. Różnorakie akty ludzkie, które powinny się stawać aktami ludzkimi $\mathrm{w}$ sensie moralnym, wypływają z natury, odrodzonej na nowo przez zbawczą łaskę Boga. Musimy i możemy mieć nadzieję, że do takich aktów będziemy zdolni. Tak rozumiana teologia nadziei, której rozwój poszedł w kierunku antropologii, spełnia równocześnie pewien istotny postulat współczesnej teologii. To, czy teologia jest w ogóle możliwa, zależy dzisiaj od umiejętności mówienia o człowieku w specyficznie teologiczny sposób. Wszelkie mówienie o Bogu może być zrozumiałe tylko wtedy, gdy słuchacz doświadcza istotnego znaczenia wypowiadanych treści dla niego samego, dla rozumienia siebie i dla swej praktycznej orientacji życiowej. Ponadto teologia jest możliwa tylko wtedy, gdy tego rodzaju antropologiczna hermeneutyka nie zamienia się w antropologiczną redukcję. Antropologiczna hermeneutyka oznacza możliwość pokazania, że wszędzie tam, gdzie mówi się o Bogu, jest zarazem mowa o człowieku. Antropologiczna redukcja natomiast polegałaby na tym, że tam, gdzie się mówi o Bogu, w gruncie rzeczy jest jeszcze mowa tylko o człowieku, tak iż w końcu posługiwanie się słowem „Bóg” staje się całkowicie zbyteczne. Teologiczna antropologia nadziei dokonuje tego, czego spodziewamy się od antropologicznej hermeneutyki - czyni zrozumiałym mówienie o Bogu, pokazując przy tym, że wchodzi tutaj w grę własny problem człowieka. Ale nie staje się ona jednak antropologiczną redukcją. Słowo „Bóg” nie staje się tutaj pseudonimem samego tylko mówienia o człowieku. Mówić bowiem o Bogu znaczy tyle, co mówić o kimś takim, kto - jako jedyny - może obdarzać człowieka umiejętnością i zdatnością (a więc „,cnotą") do nadziei.

Przekład: Ks. Wojciech Paluchowski CM 